\title{
The Role of Evaluative Thinking in the Teaching of Evaluation
}

Thomas Archibald Virginia Tech

\begin{abstract}
In this practice note, I share some reflections on the role of evaluative thinking in the teaching of evaluation. I teach an introductory graduate-level evaluation course to Master's and doctoral students, and I provide Evaluation Capacity Building (ECB) workshops to various community-based education organizations, non-governmental organizations, non-profits, foundations, and groups of emerging evaluators. In this practice note I use a reflective case study augmented with analysis against salient theoretical frameworks to reflect on evaluative thinking as a way to balance teaching theory and practice; infuse adult education principles and practices, which can also help learners hone in on the potential for evaluation for social justice; and equip students for continuing professional development-helping them become lifelong learners in evaluation.
\end{abstract}

Keywords: evaluation capacity building, evaluative thinking, practical wisdom, reflective practice, teaching of evaluation

Résumé : Dans cette note sur la pratique, je partage certaines réflexions sur le rôle de la pensée évaluative dans le cadre de l'enseignement de l'évaluation. Je donne un cours d'introduction à l'évaluation pour les étudiantes et les étudiants à la maîtrise et au doctorat, et joffre des ateliers sur le renforcement des capacités en évaluation à diverses organisations communautaires éducatives, à des organisations non gouvernementales, à des organismes à but non lucratif, à des fondations et à des groupes d'évaluatrices et d'évaluateurs émergents. Dans la présente note sur la pratique, j'utilise une étude de cas de façon réflexive, avec une analyse fondée sur des cadres théoriques reconnus, pour réfléchir à la pensée évaluative comme façon d'équilibrer la théorie et la pratique d'enseignement; comme composante des principes et des pratiques de léducation permanente, ce qui pourrait aussi aider les apprenantes et les apprenants à reconnaître le potentiel de justice sociale de l'évaluation; et comme outil de perfectionnement continu des étudiantes et des étudiants, qui les aidera à continuer l'apprentissage de l'évaluation durant toute leur vie.

Mots clés : renforcement des capacités d'évaluation, pensée évaluative, sagesse pratique, pratique réflexive, enseignement de lévaluation

Corresponding author: Thomas Archibald, Litton Reaves Hall, Virginia Polytechnic Institute and State University, 174 West Campus Drive, Blacksburg, VA, 24060; tgarch@vt.edu 
The purpose of this practice note is to share some reflections gleaned through my dual role teaching evaluation to graduate students and facilitating evaluation capacity building (ECB) for program implementers. Specifically, I focus on the role of evaluative thinking in the teaching of evaluation. As a faculty member in the United States in the Agricultural, Leadership, and Community Education department of Virginia Tech, I teach an introductory graduate-level evaluation course called "Evaluation of Extension and Outreach Programs" to Master's and doctoral students. I also provide ECB workshops to various community-based education organizations (such as the Cooperative Extension system), non-governmental organizations, non-profits, foundations, and groups of emerging evaluators.

The approach I use in this practice note is a reflective case study augmented with analysis against salient theoretical frameworks (i.e., pre-existing thought traditions that are well placed to help us better understand evaluative thinking and explore its application in the teaching of evaluation). I reflect on evaluative thinking as a way to balance teaching theory and practice; infuse adult education principles and practices, which can also help learners hone in on the potential for evaluation for social justice; and equip students for continuing professional development-helping them become lifelong learners in evaluation.

First, before introducing the "what" of evaluative thinking, I briefly consider some practical differences between formal (university teaching) and non-formal (ECB) contexts, a distinction that, surprisingly, has not been thoroughly discussed elsewhere (McFadden \& Williams, 2020). This distinction matters for this practice note because, I propose, evaluative thinking is salient and essential in the teaching of evaluation regardless of context, yet its operationalization and utility as a concept vary at least in part whether one is in a formal or non-formal context. As such, I mention a few germane considerations about those contextual differences here:

- The professional role (current or future) of the learner. Formal evaluation teaching tends to prepare emerging evaluators, or at least people whose professional roles are likely to include a strong dose of evaluation-related tasks, whereas non-formal ECB programs are more often tailored to program implementors who do not think of themselves as evaluators.

- The centrality of evaluator competencies. Formal evaluation teaching is likely to refer to and leverage explicit lists and descriptions of evaluator competencies, such as the Canadian Evaluation Society competencies (https://evaluationcanada.ca/competencies-canadian-evaluators; see also: Buchanan \& Kuji-Shikatani, 2014; Dewey et al., 2008; Galport \& Azzam, 2017; Ghere et al., 2006; Gullickson et al., 2019; LaVelle, 2019), as a pedagogical roadmap or guidepost, part of the enculturation of learners into the professional world of evaluation. In an ECB context, in contrast, the full gamut of evaluator competencies is likely too much to include, and might overwhelm and intimidate the learners. 
- The use of a syllabus. Formal evaluation teaching relies on a syllabus, whereas ECB contexts are more often based on an agenda for a workshop or workshop series. Both establish learning objectives, but they tend to vary in both form and content. Where and how evaluative thinking content and approaches show up in the learning plan thus vary accordingly.

- The duration and depth of training. Formal evaluation teaching ranges from one or two semesters of coursework through a full degree in evaluation and is characterized by a relative breadth and depth of topics, usually a practicum project, and an expectation that the learner will master many technical and conceptual aspects of evaluation. ECB contexts, on the other hand, while hopefully longer and more in-depth than just a one-off workshop (Preskill \& Boyle, 2008), still tend to be shorter and less comprehensive than formal programs.

- The role of grading and credit. Formal evaluation courses are graded and confer academic credit on the learner, whereas ECB, like most professional development, is not graded and does not lead to academic credit (though micro-credentialing, "badges," and the like are increasingly used). As such, the dynamics of intrinsic and extrinsic motivation of the learner tend to vary across these contexts, which also has implications for how evaluative thinking is approached.

Below, I refer back to these distinctions to suggest how and why evaluative thinking has a role in both teaching and training contexts.

\section{WHAT IS EVALUATIVE THINKING?}

Evaluative thinking is an ancient practice, much older than the field of professional evaluation. According to Scriven (2013), it likely emerged along with the evolution of early hominids around 2.25 million years ago-a perspective also reflected in Campbell's (1974) evolutionary epistemology (specifically the "Evolution of Epistemological Mechanisms" variety), as well as in House's (2015) interpretation of Kahneman's (2011) dual-system theory of cognition: "evaluative thinking plays a huge role in the 'fast and slow' dual process model of thinking" (pp. 17-18), which Kahneman traces to the origins of evolutionary development.

The concept of evaluative thinking, however, has not been carefully or widely discussed in the literature until relatively recently. What is evaluative thinking? From their perspective as practitioners and researchers of ECB, Buckley et al. (2015) have defined it as

critical thinking applied in the context of evaluation, motivated by an attitude of inquisitiveness and a belief in the value of evidence, that involves identifying assumptions, posing thoughtful questions, pursuing deeper understanding through reflection and perspective taking, and informing decisions in preparation for action. (p. 378) 
This definition's alignment of evaluative and critical thinking raises the question of how and to what extent those two types of thinking differ. Critical thinking has been defined as a cognitive process of reappraising ideas and thoughts in order to make more informed decisions and actions (Brookfield, 2012). Scholars such as Schwandt (2018), Vo et al. (2018), and others have further differentiated evaluative and critical thinking by aligning evaluative thinking more explicitly with the logic of evaluative reasoning, foregrounding the essential place of evaluative thinking in the fundamental yet often neglected or obfuscated evaluative synthesis step-whereby the evaluator marshals evidence in service of a value claim. As I discuss below in relation to my reflective case study, the existence of these differing yet overlapping and related perspectives on evaluative thinking helps make the case for why it is such an important concept in the teaching of evaluation. From both perspectives, evaluative thinking is key to helping learners grasp that "evaluation is a disposition and worldview" (LaVelle \& Donaldson, 2015, p. 40), an essential element of "being an evaluator" (Podems, 2018).

\section{BALANCING TEACHING THEORY AND PRACTICE}

In my course and in my ECB programs, learners are understandably eager to learn the "how to" of evaluation, the technical know-how and skills necessary to be a competent evaluation practitioner. This is usually what gets them in the door. They want to know how to make a good survey or logic model, or how to do qualitative and quantitative analysis. As important as these technical competencies are, they remain secondary to understanding the conceptual and even philosophical underpinnings of evaluation practice. That is why the textbook I use (Mertens \& Wilson, 2018) begins with an in-depth study of the major branches of evaluation and their concomitant paradigmatic assumptions-on epistemology, ontology, and axiology as well as methodology. And it is why Schwandt (2015) has written repeatedly and convincingly about his "longstanding concern that training in technique in evaluation must be wedded to education in both the disposition and the capacity to engage in moral, ethical, and political reflection on the aim of one's professional undertaking" (p. 9). To use Schwandt's (2015) phrase, this has to do with "cultivating a life of the mind for practice." It is about practical reason, which "values embodied responsibility as the resourceful blending of critical intelligence with moral commitment" (Sullivan \& Rosin, 2008, p. xvi). This is closely aligned with House's (2015) notion of practical wisdom-skilled evaluators use clinical expertise to "recognise patterns, perceive and frame situations, draw on intuition, deliberate on available courses of action, empathise, balance conflicting aims, improvise, make judgments and act in ways appropriate to the time and circumstances" (Astbury, 2016, p. 64). McDavid et al. (2019) and Houle et al. (2018) have also discussed the importance of practical wisdom, or phronesis, for an ethical evaluation practice, touching as well on the question of how evaluator education and ECB can help develop such practice wisdom. 
In my course and ECB programs alike, I use the notion of evaluative thinking to intentionally and explicitly foreground practical wisdom in evaluation. In class, for the first meeting of the semester, I use a "scenario analysis" activity adapted from Brookfield's (2012) work on teaching for critical thinking to help students identify and question assumptions. I also interweave discussions and readings not normally associated with evaluation-such as Biesta (2010) and Law (2004) - alongside Mertens and Wilson's (2018) introduction of paradigmatic assumptions to help students expand their frames of reference as to which theoretical and philosophical considerations can contribute to good evaluation practice. In ECB programs, whenever the context permits it, I include a section on using evaluative thinking to rethink what counts as credible evidence in program evaluation (see Archibald, 2019; Donaldson et al., 2014). Almost without fail, the majority of ECB participants engage enthusiastically and even passionately with this topic-as if these ideas had been bouncing around in their heads (i.e., the seeming irrationality and injustice of favouring some types of evaluation evidence over others a priori) but they just lacked access to the "academic" backing for such ideas. Including such a session in an ECB program helps participants go beyond the technical side of evaluation capacity to reflect more explicitly on the politics of knowledge in their own evaluation and program planning work.

\section{INFUSING ADULT EDUCATION PRINCIPLES AND PRACTICES: THE CRITICALLY REFLECTIVE EVALUATOR}

The ECB literature and, to a somewhat lesser extent, the teaching of evaluation literature both draw on andragogy as well as pedagogy. Chaplowe and Cousins (2016), for example, have a section on adult learning in their book, Monitoring and Evaluation Training: A Systematic Approach, while Preskill and Boyle (2008) discuss "adult learning (e.g., social constructivism, transformational learning, experiential learning), [and] workplace learning (e.g., situated learning, transfer of learning, and incidental, informal, formal learning)" (p. 449) as part of their multidisciplinary model of evaluation capacity building. More than ten years ago, Oliver et al. (2008) discussed the andragogy and pedagogy informing their multifaceted framework for teaching evaluation. That framework was designed to build on the strengths of self-directed adult learners, using three approaches: "cooperative learning, active learning, and self-directed learning" (p. 331).

In this same way, Archibald et al. (2018) explore the intersection of adult learning and evaluative thinking, drawing on "insights from critical adult education rooted in critically reflective practice and critical theory" (p. 109). Reflecting on my experiences as a teacher and facilitator, equipped with these theoretical lenses on the intersection of andragogy and the teaching of evaluation, I find that evaluative thinking is indeed a powerful framework for helping learners tap into the praxis of adult learning (either explicitly or implicitly) as they learn evaluation. 
Archibald et al. add two important elements to their theoretical perspective on this overlap, both of which have real implications for the practice of teaching evaluation: adult education's liberatory potential, and adult education (plus evaluative thinking) as a catalyst for reflective practice.

Adult education has a long (though often neglected) tradition of helping adults gain critical consciousness about the power-laden forces that influence their lives (Brookfield \& Holst, 2011; Freire, 1970). As for evaluation,

Evaluation is not only, or even most importantly, a matter of method and design. It is also inherently and fundamentally a matter of politics and values. This is because evaluation is politically located in social contexts; it is both shaped by the political relationships and power dynamics that characterize a given context and, in turn, influences the contours and future character of these relationships. (Greene et al., 2004, p. 97)

Thus, the explicitly critical and value-driven roots of adult education and evaluation can emerge and comingle in classroom (or workshop) discussions and activities framed by evaluative thinking.

In terms of reflective practice, Archibald et al. (2018) have introduced a framework for understanding how evaluative thinking promotes reflective practice on four interrelated levels within evaluation practice. Since teaching and training in evaluation should ideally prompt critical reflection among all learners, this framework can serve as a guide for practice as teachers and facilitators choose activities and topics to encourage reflection. The four levels are macro, meso, micro, and meta. The macro level pertains to reflections on the role of evaluation (and of the evaluator) in society at large. In class or in a workshop, here one can pose explicit and direct questions such as these: Why are you studying evaluation? Why are you an evaluator? How do you envision evaluation contributing to meaningful change in the world through your work?

The meso level pertains to evaluator competencies, to "one's awareness of evaluation expertise and needs for growth, including knowing oneself as an evaluator, assessing personal needs for enhanced practice, and engaging in professional development toward that goal" (Stevahn et al., 2005, p. 52). This is a question of professional development, and thus it is highly salient to the conversation about the teaching of evaluation. The micro level pertains to the day-to-day practice of evaluation, whereby evaluators engage in reflection-in-action (Argyris, 2004) and operationalize their practical wisdom. As such, this level of reflection links back to the conversation on values, social justice, and critical praxis. The final level, meta-reflection, has to do with reflection on the three other levels, what we are able to do in practice notes such as this.

Perhaps most importantly, evaluative thinking as a catalyst for reflective practice in the teaching of evaluation can equip students for continuing professional development in evaluation-to help them become life-long learners in evaluation, supported by various communities of practice. 


\section{LESSONS AND IMPLICATIONS}

To conclude, it seems only appropriate for me to practice a little evaluative thinking and meta-reflection on the reflections shared herein, summarized in a succinct list of lessons and implications for the practice of teaching evaluation. One line of questioning is in regard to the practical implications of the differences between formal (university teaching) and non-formal (ECB) contexts introduced above. I believe that, as my theory-informed case reflections suggest, evaluative thinking has a major role in both teaching contexts. In formal contexts, it can be connected to almost all parts of the syllabus, in line with the various lists of evaluator competences and guiding principles (especially the ones linked to reflective practice, the common good, etc.). Activities focused on evaluative thinking can be used as a way to kick off the semester, or to help students process paradigm debates. On the other hand, in ECB workshops, even if the competencies are not explicitly part of the conversation, the facilitator can use evaluative thinking as a way of structuring the agenda, since it is a rather ubiquitous concept once you begin using it as a framework or lens. Some specific ways in which these lessons and implications for the practice of teaching evaluation can be operationalized include the following:

- unpacking specific competencies, guiding principles, and steps in the evaluation process to discuss and identify the ways in which evaluative thinking is represented or manifested therein;

- doing a scenario analysis activity adapted from Brookfield's (2012) work on teaching for critical thinking to help students identify and question assumptions;

- engaging in dialogic critical reflection on paradigmatic assumptions, including the methodological question of what counts as credible evidence, facilitated via reading vignettes or doing a role play applying different paradigms to a common case;

- connecting to learners' existing reservoir of experience with everyday evaluative thinking, augmented by a deeper examination sparked by guiding questions (e.g., Brookfield's critical conversations protocol, etc.); this pedagogical approach also foregrounds the role of values and valuing in evaluative thinking; and

- journalling based on the four levels of critically reflective practice for evaluators as described in Archibald et al. (2018).

In conclusion, from my experience across varied and numerous cases of teaching or training on evaluation, evaluative thinking has provided a through-line of thought and action to help demystify theory and remystify practice (Lederach et al., 2007), highlight the value-laden and social justice implications of the work, and call into question problematic assumptions about evidence, methods, power, and the very role of evaluation in society. That is why, from my standpoint, I have found that evaluative thinking has an essential role in the teaching of evaluation. 


\section{REFERENCES}

Archibald, T. (2019). Whose extension counts? A plurality of extensions and their implications for credible evidence debates. Journal of Human Sciences and Extension, 7(2), 22-35.

Archibald, T., Neubauer, L. C., \& Brookfield, S. D. (2018). The critically reflective evaluator: Adult education's contributions to evaluation for social justice. In A. T. Vo \& T. Archibald (Eds.), Evaluative thinking: New directions for evaluation (vol. 158, pp. 109-123).

Argyris, C. (2004). Reasons and rationalizations: The limits to organizational knowledge. Oxford University Press.

Astbury, B. (2016). Reframing how evaluators think and act: New insights from Ernest House. Evaluation, 22(1), 58-71. https://doi.org/10.1177/1356389015623125

Biesta, G. J. J. (2010). Why "what works" still won't work: From evidence-based education to value-based education. Studies in Philosophy and Education, 29(5), 491-503. https://doi.org/10.1007/s11217-010-9191-x

Brookfield, S. D. (2012). Teaching for critical thinking: Tools and techniques to help students question their assumptions. Jossey-Bass.

Brookfield, S. D., \& Holst, J. D. (2011). Radicalizing learning: Adult education for a just world. Jossey-Bass.

Buchanan, H., \& Kuji-Shikatani, K. (2014). Evaluator competencies: The Canadian experience. Canadian Journal of Program Evaluation, 28(3), 29-47.

Buckley, J., Archibald, T., Hargraves, M., \& Trochim, W. M. (2015). Defining and teaching evaluative thinking: Insights from research on critical thinking. American Journal of Evaluation, 36(3), 375-388. https://doi.org/10.1177/1098214015581706

Campbell, D. T. (1974). Evolutionary epistemology. In P. A. Schilpp (Ed.), The philosophy of Karl R. Popper (pp. 412-463). Open Court.

Chaplowe, S. G., \& Cousins, J. B. (2016). Monitoring and evaluation training: A systematic approach. Sage.

Dewey, J. D., Montrosse, B. E., Schröter, D. C., Sullins, C. D., \& Mattox, J. R. (2008). Evaluator competencies: What's taught versus what's sought. American Journal of Evaluation, 29(3), 268-287. https://doi.org/10.1177/1098214008321152

Donaldson, S. I., Christie, C. A., \& Mark, M. M. (Eds.). (2014). Credible and actionable evidence: The foundation for rigorous and influential evaluations. Sage.

Freire, P. (1970). Pedagogy of the oppressed (M. B. Ramos, Trans.). Continuum.

Galport, N., \& Azzam, T. (2017). Evaluator training needs and competencies: A gap analysis. American Journal of Evaluation, 38(1), 80-100. https://doi.org/10.1177/109 8214016643183

Ghere, G., King, J. A., Stevahn, L., \& Minnema, J. (2006). A professional development unit for reflecting on program evaluator competencies. American Journal of Evaluation, 27(1), 108-123. https://doi.org/10.1177/1098214005284974

Greene, J., Millet, R., \& Hopson, R. (2004). Evaluation as democratizing practice. In M. Braverman, N. Constantine, \& J. K. Slater (Eds.), Putting evaluation to work for foundations and grantees (pp. 96-118). Jossey-Bass. 
Gullickson, A. M., King, J. A., LaVelle, J. M., \& Clinton, J. M. (2019). The current state of evaluator education: A situation analysis and call to action. Evaluation and Program Planning, 75, 20-30. https://doi.org/10.1016/j.evalprogplan.2019.02.012

Houle, S., Hurteau, M., \& Bourgeois, I. (2018). Lévaluation de programme axée sur la rencontre des acteurs : une sagesse pratique. Presses de l'Université du Québec.

House, E. R. (2015). Evaluating: Values, biases, and practical wisdom. Information Age Publishing.

Kahneman, D. (2011). Thinking, fast and slow. Farrar, Straus and Giroux.

LaVelle, J. M. (2019). Educating evaluators 1976-2017: An expanded analysis of university-based evaluation education programs. American Journal of Evaluation, 41(4), 494-509. https://doi.org/10.1177/1098214019860914

LaVelle, J. M., \& Donaldson, S. I. (2015). The state of preparing evaluators. New Directions for Evaluation, 145, 39-52.

Law, J. (2004). After method: Mess in social science research. Routledge.

Lederach, J. P., Neufeldt, R., \& Culbertson, H. (2007). Reflective peacebuilding: A planning, monitoring and learning tool kit. Joan B. Kroc Institute, University of Notre Dame/ CRS.

McDavid, J. C., Huse, I., \& Hawthorn, L. R. (2019). Program evaluation and performance measurement: An introduction to practice (3rd ed.). Sage.

McFadden, A., \& Williams, K. E. (2020). Teachers as evaluators: Results from a systematic literature review. Studies in Educational Evaluation, 64. Article 100830. https://doi. org/10.1016/j.stueduc.2019.100830

Mertens, D. M., \& Wilson, A. T. (2018). Program evaluation theory and practice (2nd ed.). Guilford.

Oliver, D. E., Casiraghi, A. M., Henderson, J. L., Brooks, A. M., \& Mulsow, M. (2008). Teaching program evaluation: Three selected pillars of pedagogy. American Journal of Evaluation, 29(3), 330-339. https://doi.org/10.1177/1098214008319876

Podems, D. R. (2018). Being an evaluator: Your practical guide to evaluation. Guilford.

Preskill, H., \& Boyle, S. (2008). A multidisciplinary model of evaluation capacity building. American Journal of Evaluation, 29(4), 443-459. https://doi.org/10.1177/1098214008 324182

Schwandt, T. A. (2015). Evaluation foundations revisited: Cultivating a life of the mind for practice. Stanford University Press.

Schwandt, T. A. (2018). Evaluative thinking as a collaborative social practice: The case of boundary judgment making. New Directions for Evaluation, 2018(158), 125-137. https://doi.org/10.1002/ev.20318

Scriven, M. (2013). The past, present and future of evaluation. Keynote presented at the Australasian Evaluation Society Conference, Melbourne.

Stevahn, L., King, J. A., Ghere, G., \& Minnema, J. (2005). Establishing essential competencies for program evaluators. American Journal of Evaluation, 26(1), 43-59. https://doi. org/10.1177/1098214004273180

Sullivan, W. M., \& Rosin, M. S. (2008). A new agenda for higher education: Shaping a life of the mind for practice. Jossey-Bass. 
Vo, A. T., Schreiber, J. S., \& Martin, A. (2018). Toward a conceptual understanding of evaluative thinking. New Directions for Evaluation, 2018(158), 29-47. https://doi. org/10.1002/ev.20324

\section{AUTHOR INFORMATION}

Thomas Archibald is an associate professor and extension specialist in the Department of Agricultural, Leadership, and Community Education at Virginia Tech, where he also directs the Feed the Future Senegal Youth in Agriculture project. His research and practice focus primarily on evaluation capacity building and evaluative thinking. 